\title{
A Basic Discourse on Discipline for Novice Teachers
}

\author{
Lucie Kucerova, Tereza Buchtova, Stefan Chudy, Pavel Neumeister \\ Olomouc Department, Faculty of Education, Palacky University, Olomouc, Czech Republic \\ Email: kucerova.lucie-pv@seznam.cz
}

Received 7 January 2015; accepted 22 January 2015; published 29 January 2015

Copyright (C) 2015 by authors and Scientific Research Publishing Inc.

This work is licensed under the Creative Commons Attribution International License (CC BY). http://creativecommons.org/licenses/by/4.0/

c) (i) Open Access

\begin{abstract}
This paper presents a research investigation focused on creating a basic discourse on discipline in novice teachers. The qualitatively-chosen methodology identifies, for a selected sample, how length of pedagogical experience and gender influence the creation and maintenance of a teacher's authority in the classroom. This research is a part of the project, which focuses on mapping the different approaches of education for novice teachers to PDF Palacky University in Olomouc. The aim is to highlight the possible theoretical and methodological approaches in addressing the issue of discipline than on specific statistical data.
\end{abstract}

\section{Keywords}

Discipline, Authority, Motivation, Novice Teacher, The Conceptual Mapping Method, Narrative Analysis

\section{Introduction}

Discipline represents order, a procedure that is essential for students to be able to learn effectively. There is extensive literature on discipline in schools, which also includes a series of books that provide good practical information and advice. The problems and issues of discipline are thus one of the essential topics for pedagogical students, and one of the most essential areas of further education [1].

Teachers' educational activities in the classroom can be relatively easily observed; but however, is this true for educational activities? Teachers do not talk about their individual conception of educational activities, but despite this they prepare themselves to teach and organize life in the classroom. Therefore, in order to carry out their educational activities, they need to have an awareness and knowledge of educational resources that will enable them to do so.

This group also includes planning, controlling and maintaining discipline in the classroom. Discipline is an 
important prerequisite not only for the functioning of a classroom, but also of society as a whole. This field is very demanding, whether for teachers with years of experience, and especially for novice teachers or student teachers. Novice teachers however, are not really concerned with this topic specifically—until they encounter a particular problem.

This contribution's aim is to shed especial light on particular theoretical issues in the form of a discourse on the concept of discipline as an educational resource for novice teachers; on the basis of a definition of discourse-understood as a statement about the functioning of human societies' established perceptions. Achievement of the main goal was conditional on the fulfilment of the specific subsidiary objectives where throughout the research process, this paper focuses only on the qualitative part of the collection and analysis of the data; and it only presents the main findings.

\section{Theoretical Background}

The concept of discipline can be viewed from the perspective of multiple meanings. Each person perceives discipline differently — for example, simply as obedience, a set of rules of behaviour or habits acquired through education and/or training. These views are, to a greater or lesser extent, close to the truth [2].

Discipline, as a complex phenomenon, affects people's lives every day. According to Bendl, discipline can be defined as: "conscious adherence to specified behaviour norms" [3].

One such important aspect is pedagogical discipline, closely associated with education. Pedagogical discipline is focused on the child. Thereby, the given nature learns to subordinate itself to authority. If one talks about the goal of discipline, this is understood to mean that discipline has to create a useful member of the state from a student, and shall create a structured student life and teach them what the state needs from citizens; that is to say, obedience to the laws [4].

Interpretations of discipline differ as do the different approaches of individual authors. The aforementioned Bendl, states that one can approach the interpretation of discipline according to areas like, the aim of discipline, and its function and content, the establishment of standards and norms, a sense of responsibility for discipline, and the further development of discipline and methods [5].

One can designate several phenomena as causes of indiscipline, or the syndrome of risky behaviour. These phenomena can include for instance things like substance abuse, and negative phenomena in the reproductive and psychosocial fields. Negative phenomena in the reproductive field include for example, overly early initiation of a sexual life or excessive changing of sexual partners. Negative phenomena in the psychosocial field include aggression, behaviour disorders, or depression [5]. Other causes of indiscipline include: the pedagogue, teaching activities, and aspects of behaviour, or emotional and physiological reasons, the environment as well as a student's personality and their relationship to the learning process. These causes of disorderly behaviours are those most often manifested.

One of the ways of maintaining discipline among students is that the teacher has authority—and it is precisely this authority of the teacher which is the prerequisite not only of teaching success, but also the observance of discipline. Authority can be divided as follows:

- Personal-primary, or also, natural.

- Functional-i.e. professional.

- Positional-i.e. secondary.

- Formal-resulting from one's position in the organisational chart.

- Informal—resulting from skills, talent, education, etc. [6].

These types of authority work together; sometimes, one replaces another. The ideal situation is then, that a teacher had informal authority which flows from their control of their subject, the extent of their pedagogical competencies, and also-from a good relationship with their pupils. This is however, not as simple for example for novice teachers, because the pedagogical competence of maintaining discipline (i.e. the teacher has authority) is very complicated and teachers must work on it [6]. How then can a teacher build authority? This process is dependent on the expression of status, pedagogical competence, teachers themselves, and the effective and equitable resolution of situations where the teacher has to deal with pupils' undesirable behaviour as well as consistency between a teacher's words and actions. This listing is for a teaching assistant, on just how to build authority. Different influences affect the students and their inappropriate behaviour, and a teacher's authority is also one [6]. 
One of the most important features in the creation of a positive climate in the classroom, which acts on pupils' discipline, is motivation. Just as teachers' authority is important, so too is it also important to motivate students to not even think of inappropriate behaviour. When motivating, it is important that pupils are motivated from several different directions. This involves their internal motivation, external motivation and pupils' expectations of success [1]. Internal motivation includes the degree to which students participate in certain activities so as to meet their needs; these include curiosity, interest in the actual topic, and also to be able to gain skills and abilities. Extrinsic motivation can include their actual participation in activities so as to achieve the specifically defined goals. Internal and external motivations are often pitted against each other, but this does not mean that they are incompatible. The third motivation strength is their expectation of success. This expectation is associated with how students feel that the given activities can help them to achieve success [1].

"Rules" or "Principles" exist, by means of which it is not only possible to resolve indiscipline, or at least to confront indiscipline and to fight it preventively. So how then does one deal with indiscipline and ensure the prevention of indiscipline? For example, the discovery of indiscipline or insubordination, exposing the causes of indiscipline, the use of a diverse range of educational resources, the introduction of lectures for pedagogues, and the inclusion of social pedagogues and school psychologists in schools and other establishments [7].

\section{Research Questions}

The main research goal was to create a basic discourse on discipline in novice teachers, through the analysis and summarisation of the essential components of the disciplinary techniques by which pedagogues manage pupils' indiscipline in school classrooms. This investigation was carried out in several empirical stages. An important goal in the analysis process was just this creation of the aforementioned discourse on discipline in the educational activities novice teachers [8]. The empirical validation of the functionality of discourse served for these purposes.

The survey had to be implemented in several consecutive steps. Some of the basic theoretical analysis steps form the basis for the empirical investigation, and conversely, data from the empirical investigations assist in the creation of the perspectives and internal structure of this discourse. The chosen methodology serves as the basis for the optimalisation of the discourse. The main objective of the work was divided into sub-goals, which are readily seen in the form of the specific focus of the various stages of the work of creating and subsequently verifying the functionality of this discourse.

Analysis of the given sample and the respondents' typology in comparison with the theory as determined forms the basis of the validity and reliability of the research. This analysis is supplemented by the Cluster Analysis and Factor Analysis of data elements, which means that evaluation and inappropriate influences are eliminated from the empirical research (e.g. the randomness of answers, incorrect answers, and so on); and it also optimises the validated rating system data (i.e. the credibility of the data). The verification of the independence of the evaluations of respondents' preferences, and for instance, their attitudes, is resolved by using Non-parametric Tests for Ordinal Data Types in dual and multiple comparisons. The empirical research was realized in the following steps:

- The selection of the sample and the identification of respondents.

- The elimination of undesirable elements (e.g. tendency to mediocrity, etc.).

- The establishment of the research assumptions.

- The specification, optimization and innovation of research tools.

- The modification of the research sample.

- The implementation of the empirical investigation.

- And, the verification of the independence of the optimized data system.

The context of the research investigation is based on factor and cluster analysis of elements to verify and determine the assumptions and hypotheses. It is precisely this use of factor analysis which does not allow the creation of classic hypotheses [9]. When applying this method, it is not possible to define classical hypotheses that the use of other statistical methods would allow [10]. With a view to these facts and the nature of the empirical data obtained, as well as for the content and purpose of creating this discourse-where the basic premise is the specification of the characteristic elements of the concept of discipline as a means of educationally-influencing novice teachers, it was decided to set the research assumption and verify it in the preliminary research stage and thereby to reduce variables to the desired number needed to specify the discourse with respect to the theoretical definition. Verification using Cluster Analysis is in line with the stated goal of this research. 
One of the important characteristics for its use in practice is its clarity and use in the evaluation system's operations-i.e. its independence and support of important respondent characteristics. Other factors include gender and length of working experience. The research sample of novice teachers is subjected to simple Descriptive Statistics. In the context of the pilot study, assumptions were established and then were subsequently subjected to statistical verification, and further specified. Based on the preliminary research, the following hypotheses were created for the main empirical research:

- The length of working practice does not influence the formation and maintenance of teachers' authority in the classroom, this hypothesis monitors the difference between the length of working practice and, secondarily, also between sexes in the creation of authority (i.e. teacher rigor, maintaining order and quiet, re-seating pupils, insistence on compliance with the School Regulations, etc.).

- There is no statistically significant difference between men and women in their perception of disciplinary measures for maintaining the teacher's authority in the classroom, this hypothesis expresses an effort to uncover and describe the relationship between discipline and gender differences in the perception of disciplinary resources between men and women.

- Teachers, unlike lady teachers, perceive the importance of determining the precise rules in the classroom because of their importance for the observance of discipline, this hypothesis enables the tracking and revelation of the causes of such perceptions and the building of relationships between a teacher and a student; here, the interesting variables are gender and the seniority of the teachers.

- In the course of building teachers' responsibility towards their educational work in the classroom, length of practice does not play an important role, the aim is to describe the level of responsibility, which is expressed by the relationship between their profession; and, it is assumed that a significant difference exists in the length of individual respondents' working practice and their relationship to their profession.

- In the course of repeated violation of the disciplinary rules, compliance is required more by teachers with minimal experience, this hypothesis captures part of the discourse which expresses the methodological concept of discipline and focuses on building a relationship between a teacher and student in the sense of discipline as an educational element.

Differences exist in the creative creation of disciplinary techniques between men and women, this presupposes the use of creativity in teachers' work and for setting the rules for building a relationship between a teacher and pupil and follows the pupil's acceptance of disciplinary elements.

\section{Methodology}

Conceptual Mapping and Projection Techniques using Incomplete Sentences were used in the data collection phase, as well as to create a structure defining the basic aspects and concepts of the discourse method [11]. Conceptual Mapping (i.e. thought maps, mind mapping) was used as a data collection method for structuring concepts [12], schematic concepts and depicting their mutual interrelationships. Conceptual mapping served for "uncovering" the "ontological structures" of thinking in students and novice teachers [13]. The clear structuring and reconstruction of the conceptual apparatus at different levels of generality, over a certain time interval, and on the basis of their own experience provides very suggestive material for the analysis of, and the creation of a concept and focus of the discourse. Thanks to this method we are able to understand changes in thinking and structuring concepts; processing style whether as graphomotoric expressions or constructivist deliberation and to capture the meaning of terms by using concepts, signs or symbols.

Janík, distinguishes two kinds of conceptual maps-structured and unstructured. Input variables expressed as a fixed list of terms are presented in the Structured Conceptual Maps. Unstructured mapping, presented by means of a central concept and whose purpose is to search for related concepts of content, sensory data, and the like [14]. In the context of this research investigation, the concept mapping focus is oriented on the scope and content of discourse; and thus, the creation of structures and related concepts that formed the imaginary boundary of a discourse. The creation of the structure of concepts of discipline and the concepts associated with it, are demonstrated in the conceptual maps presented herein in reflection of the clarification function, and for the visualisation and presentation of ontological structures. These maps illustrate novice teachers' perception of the conceptual apparatus and uncover the level of the ontological foundation of the concept of discipline and disciplinary techniques.

The Unfinished Sentences Method was utilized for further research. This is a method with a written charac- 
ter, used for its freedom in space and spontaneity of expression. It serves for the investigation of non-cognitive characteristics, attitudes, opinions and beliefs. Stimuli, in the form of words or phrases, evoke the possibility of creating answers. Space for answers is given by the bond to other inspirational phrases or words and the possibilities offered by writing is expressed by the size of the "room to respond" for the answer. These sentences in the investigation were formulated as incomplete statements-which respondents completed by finishing them. The resulting data is Incomplete Statements that are expressed in the overview tables and placed in the context of the discourse content. Thanks to this technique, extensive material was obtained (since the sample consisted of 190 novice teachers).

Narrative Analysis was used in the course of analyzing the written responses of novice teachers, where their portfolio from their periods of study at the Faculty of Pedagogy formed a part. The sections that deal with discipline in schools were used as sources. Students were supposed to write-in different literary forms, their perceptions and experiences pertaining to discipline. The portfolio is supplemented with a new part, which contains the recollections of the qualities of a teacher in the classrooms in which the respondents participated in the role of pupils. Thanks to this analysis, it was possible to detect the hidden meanings of situations, perceptions and resolution of discipline issues.

Written responses are an excellent material source for analysis and are qualitative sources of empirical data. Novice teachers were thus able to choose their own descriptions of the situations and events which the researcher represented, who would have watched these situations themselves.

From the validity point-of-view, this has to do with an accurate description of the perceptions of the given sample of respondents and thus, the expression of the described phenomenon of perception, i.e. discipline. Narrative Analysis uses, due to the nature of the material, structural and thematic analysis components. While it thematically describes the answer to the question— what is said; it notes the structural answers to the questionhow it is said.

\section{Research Investigation Results}

An important step in the research investigation context was the representative sample, whose members would adequately and competently express themselves. In the course of defining the basic set of questions, the specific characters of the base file had to be specified [15]. The main criteria include: a minimum of working experience in a school environment, a minimal knowledge of the phenomena under investigation, personal experience with the management and organization of a classroom, a description of the subjective perception of the phenomenon being examined, and the assurance of maximum anonymity and willingness. In addition, the specification for the basic sample took place; that is to say, that the investigation would focus on fifth-year students in the Bachelor's Degree or the second-year of the Master's Degree programmes at UP PDF. Because the research was realized on PDF UP, home students were utilized as respondents who already have within a master's degree internship and fulfill the criteria chosen throughout the research.

In the initial stage of the analysis, the pilot-study sample consisted of 205 respondents. The research sample in the main phase of the research investigation was 130 respondents.

To better understand the broader context of the resolution of the problems and issues of discipline, and the concept of novice teachers in schools and classrooms in the form of discourse analysis, an analysis was performed of basic concepts and the reconstruction of the concept of discipline. The data collection methods included Unfinished Sentences, Conceptual Maps, Interviews, while the data analysis methods were Narrative and Content Analysis. The aim was to discover how the description of the basic definition of the concept of discipline forms the concept of discipline in a school environment. Novice teachers thus demonstrate that they can present the power elements of discipline in the character of its institutional and normative definitions. The key to creating a discourse on discipline as an educational resource is the fact that novice teachers expect the determination of the behaviour of the actors in the educational process in certain situations, require exact behaviour patterns and also determine the penalties for non-compliance.

The psycho-pedagogical aspects of the teacher-pupil relationship were investigated using Unfinished Sentences and their subsequent analysis. The results are processed in the form of a table (viz Appendix No. 1) Students were asked to complete Unfinished Statements (viz Appendix No. 2). Another of the activities was the discipline-building process in the form of self-discipline. Conceptual Maps served this purpose.

For novice teachers, building of "some form of relationship" is important. The discourse on discipline thus 
takes on the aspect of the creation of positive relationships and authority not based on formal institutionalized education elements. Another important role in the concept of discipline is also played by bad experience acquired in the role of a pupil. From novice teachers' responses, it became clear that bad experiences in the role of a student result in a turnaround in their perception of the role and status of teachers in the classroom.

Another sub-objective was the definition and specification of discipline as an educational resource oriented on the elements of the consolidation of power and power-relationships in the classroom.

From the information obtained above, it is clear that discipline is perceived as a component of educational activities in which reconciliation comes about between the teacher's ideas, objectives and the educational activities' content; and pupils' needs. The main objective of discipline is to optimise the environment and teacher-student interaction. The teacher thus uses their experience, personal potential, disciplinary techniques, and social control.

In order to create the discourse, the goal-description of the current state of discipline with a regard to the content and structure of discipline, was also set. The result is the implementation of disciplinary techniques in novice teachers' disciplinary concepts. For novice teachers, this is mainly about maintaining power over students, maintaining stereotypes in the course of the learning process, and coping with disciplinary educational activities as something that is already above and beyond the defined duties associated with teaching. If the basic aim of a teacher is to maintain their authority and position in the class, then they must make greater use of their use intellectual potential rather than their physical disposition. Discourse on discipline as an educational tool is formed in this way and takes on dimensions ranging from maintaining authority through the fulfilment of educational goals to the creation of the pupil-teacher relationship. This is done through disciplinary techniques.

The modality of resources is applied through many disciplinary techniques and strategies. Variability and creativity in the development, application and evaluation of disciplinary measures are well-known to novice teachers. The modality of classical and verified disciplinary techniques lies in different intensities and variations of words. Physical punishment is a rare phenomenon—but it does occur. Another element that strengthens the power relationship in the classroom is to create rules that are supported by the documents of the given institution. Most often, this process takes place through mutual consent, also complemented by penalties for non-compliance. The most common approach is that an individual teacher presents the internal regulations of the school (school rules) and subsequently enforces them by sanctions set by the school. It is less common for the approach to be that the teacher tries to solve the problem themselves, or with their parents.

The application of power relationships and power at the general level taken from the samples of the research material also point out that any application of power is also things from previous experience. The goal of discipline in the school environment is not only to maintain order and the effort to improve the quality of the teacherstudent relationship, but also the exercise of power in the teacher-role and the compensation of certain physical and psychic phenomena, as well as the justification of their actions - in front of themselves and their colleagues (i.e. rationalization).

To check discipline, teachers frequently choose the observation method and subsequently, use gestures, e.g. not only a raised finger or facial mimicry, but verbal expressions like a shout, suggestive questions, commands, etc. A specific form of discipline is supervision, which requires a certain degree of observation skills from teachers. It also requires concentration and the maintenance of the rules, as well as a certain degree of empathy, and the effort to build a teacher-pupil relationship not only based on superiority and inferiority terms. Supervision is closely connected with sanctioning, determining sanctions, and ensuring compliance, which all play a positive role in the school discipline environment.

\section{Conclusions}

The aim of this research was the creation of the theoretical basis of a discourse on discipline in novice teachers. Content and discourse analysis elements served to meet this end, as did their self-reflection on practical experiences in the teacher role. Sub-goals helped to create the basic concept of power and the use of discipline in the school environment as an educational resource. This paper mainly deals with the theoretical basis of discipline and authority in novice teachers and provides a possible methodological approach; especially in the areas of data collection methods and their subsequent analysis. The research material was obtained and processed using methods like interviews, unfinished sentences, concept mapping and the analysis of the biographical written statements of the respondents. As part of this study were not presented results of a survey, but it was focused on 
theoretical and methodological approach that is only a partial part of the research project. By setting the theoretical concept of discipline as a means of education we have fulfilled the main objective of this paper. Options of processing empirical verification of a theoretical treatment are a matter for further discussion.

The results of this research clearly show that the gender-gap between the sexes exists, and is significant. This finding provides us with a clear answer to why school-managers prefer men over women teachers in teacher recruitment. The question remains, how many male teachers can last in the school environment and overcome the initial failures linked to discipline. For this reason, the questions were also oriented on the length of practice as a factor in the formation of the teacher-pupil relationship. Respondents positively appreciated the creativity, passion, and the so-called "learning to live with experience" of the profession. They did not take length of experience as being an important factor. The answers clearly show that when solving problems with discipline, respondents would prefer first of all to resolve the issue with the class themselves; and only after that, with the school management staff, and finally, with parents. From the results, we can also conclude that gender plays an important role in the selection of disciplinary techniques and, on the contrary, that length of service is not a significant factor in influencing creativity in the use of discipline as an educational resource activity. A positive factor for novice teachers is that students take normative discipline means as something that is necessary and normal in schools.

\section{Acknowledgements}

Internal grant of PDF UP: From subjective implicit theories of education to teaching knowledge. The process of constitution of a cognitive framework sciences education in the national and international context.

IGA PdF 2014004: Mapping Approaches to describe fragments and constructs training for new teachers at Faculty of Education on UP in Olomouc.

The VOICE of European TeacherS (VOICES), 526613-LLP-2012-NL-Comenius-CNW.

\section{References}

[1] Kyriacou, Ch. (1996) Klíčové dovednosti učitele. Portál, Praha, 82, 95.

[2] Makarenko, A.S. (1957) O výchově dětí v rodině. 7. vyd. SPN, Praha, 31.

[3] Bendl, S. (2004) Jak předcházet nekázni, aneb, Kázeňské prostředky. ISV, Praha, 23.

[4] Uher, J. (1924) Problém kázně. Dědictví Komenského, Praha, 24.

[5] Bendl, S. (2011) Kázeňské problémy ve škole. Triton, Praha, 29, 34, 35.

[6] Podlahová, L. (2004) První kroky učitele. Triton, Praha, 89, 90.

[7] Bendl, S. (2001) Školní kázeň. Metody a strategie. ISV, Praha.

[8] Haining, R. (1990) Spatial Data Analysis in the Social and Environmental Science. University Press, Cambridge. http://dx.doi.org/10.1017/CBO9780511623356

[9] Hendl, J. (2004) Přehled statistických metod zpracování dat. Portál, Praha.

[10] Macdonald, R.P. (1991) Faktorová analýza a př́buzné metody v psychologii. Academia, Praha.

[11] Skalková, J. (1983) Úvod do metodologie a metod pedagogického výzkumu. SPN, Praha.

[12] Buzan, T. (2007) Mentální mapování. Portál, Praha.

[13] Bendl, S. and Voňková, H. (2010) Využití pojmových map ve výuce pedagogiky. IN: Pedagogická orientace, r. 20, č. 1, 16-38.

[14] Janík, T. (2005) Znalost jako klíčová kategorie učitelského vzdělávání. Paido, Brno.

[15] Gavora, P.(2009) Stanovení výzkumného vzorku. In: ŠVEC, Š., Ed., Metodologie věd o výchově, Paido, Brno. 
Appendix No. 1

\begin{tabular}{|c|c|c|c|}
\hline \multirow[b]{2}{*}{ Discipline is ... } & \multirow{2}{*}{$\begin{array}{l}\text { Induced } \\
\text { categories }\end{array}$} & \multicolumn{2}{|c|}{ Responses } \\
\hline & & $\begin{array}{c}\text { Absolute } \\
\text { frequency (Number) }\end{array}$ & $\begin{array}{c}\text { Relative } \\
\text { frequency (\%) }\end{array}$ \\
\hline $\begin{array}{l}\text { Order, security, safety, determined by } \\
\text { (School Rules and Regulations) }\end{array}$ & $\begin{array}{l}\text { Educational } \\
\text { aims }\end{array}$ & 54 & 19.5 \\
\hline $\begin{array}{l}\text { Comprised of education, the perception of order and } \\
\text { regulations, tidying-up, commands, prohibitions }\end{array}$ & $\begin{array}{l}\text { Educational } \\
\text { resources }\end{array}$ & 46 & 16.6 \\
\hline $\begin{array}{l}\text { Clearly established rules required by teachers associated } \\
\text { with the climate in class, the stringency of the teachers, } \\
\text { pupils' freedom, fairness to the pupils }\end{array}$ & $\begin{array}{l}\text { Teacher-pupil } \\
\text { relationships }\end{array}$ & 67 & 24.1 \\
\hline $\begin{array}{l}\text { Clearly established rules required by teachers associated } \\
\text { with the climate in class, the stringency of the teachers, } \\
\text { pupils' freedom, fairness to the pupils }\end{array}$ & $\begin{array}{l}\text { Teacher-pupil } \\
\text { relationships }\end{array}$ & 67 & 24.1 \\
\hline $\begin{array}{l}\text { Associated with family values, decency, speaking politely, } \\
\text { not using vulgar speech, (not) behaving ignorantly }\end{array}$ & $\begin{array}{l}\text { Associated } \\
\text { with values }\end{array}$ & 23 & 8.3 \\
\hline $\begin{array}{l}\text { Not breaking norms, decent behaviour, the abidance of } \\
\text { decency norms, not breaking standards }\end{array}$ & $\begin{array}{l}\text { Associated with } \\
\text { behaving oneself }\end{array}$ & 87 & 31.4 \\
\hline \multicolumn{2}{|l|}{ Overall responses evaluated: } & \multicolumn{2}{|c|}{277} \\
\hline
\end{tabular}

No. 2

Form of the unfinished sentences...

Discipline is...

Discipline in schools is...

Discipline in schools is associated with...

Discipline at school for teachers means...

Formal discipline is manifested as...

Authoritative discipline is reflected in...

Enforced discipline is reflected by...

External discipline is reflected through...

Conscious discipline is reflected...

Internal discipline is...

Informal discipline is...

Formal discipline is...

Write 5 commands in the form of declarative sentences that are important to you and that you use in practice.

Write 5 commands in the form of conditional sentences that are important to you, and which you use in practice. 
Scientific Research Publishing (SCIRP) is one of the largest Open Access journal publishers. It is currently publishing more than 200 open access, online, peer-reviewed journals covering a wide range of academic disciplines. SCIRP serves the worldwide academic communities and contributes to the progress and application of science with its publication.

Other selected journals from SCIRP are listed as below. Submit your manuscript to us via either submit@scirp.org or Online Submission Portal.
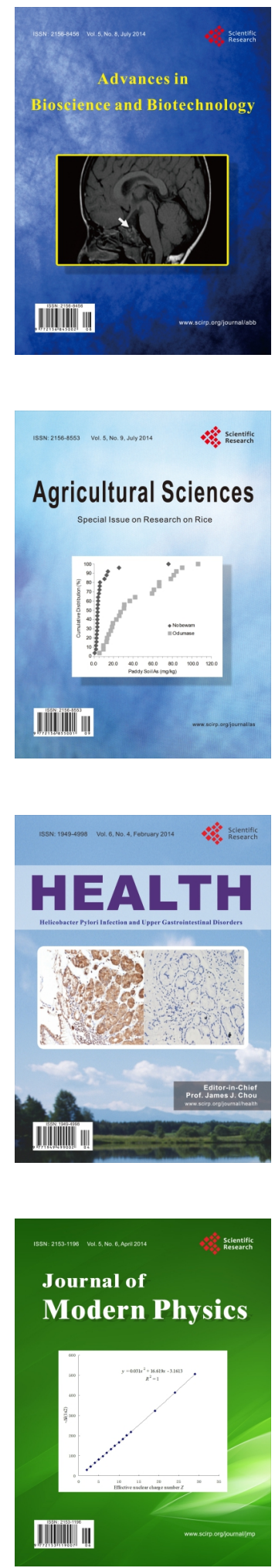
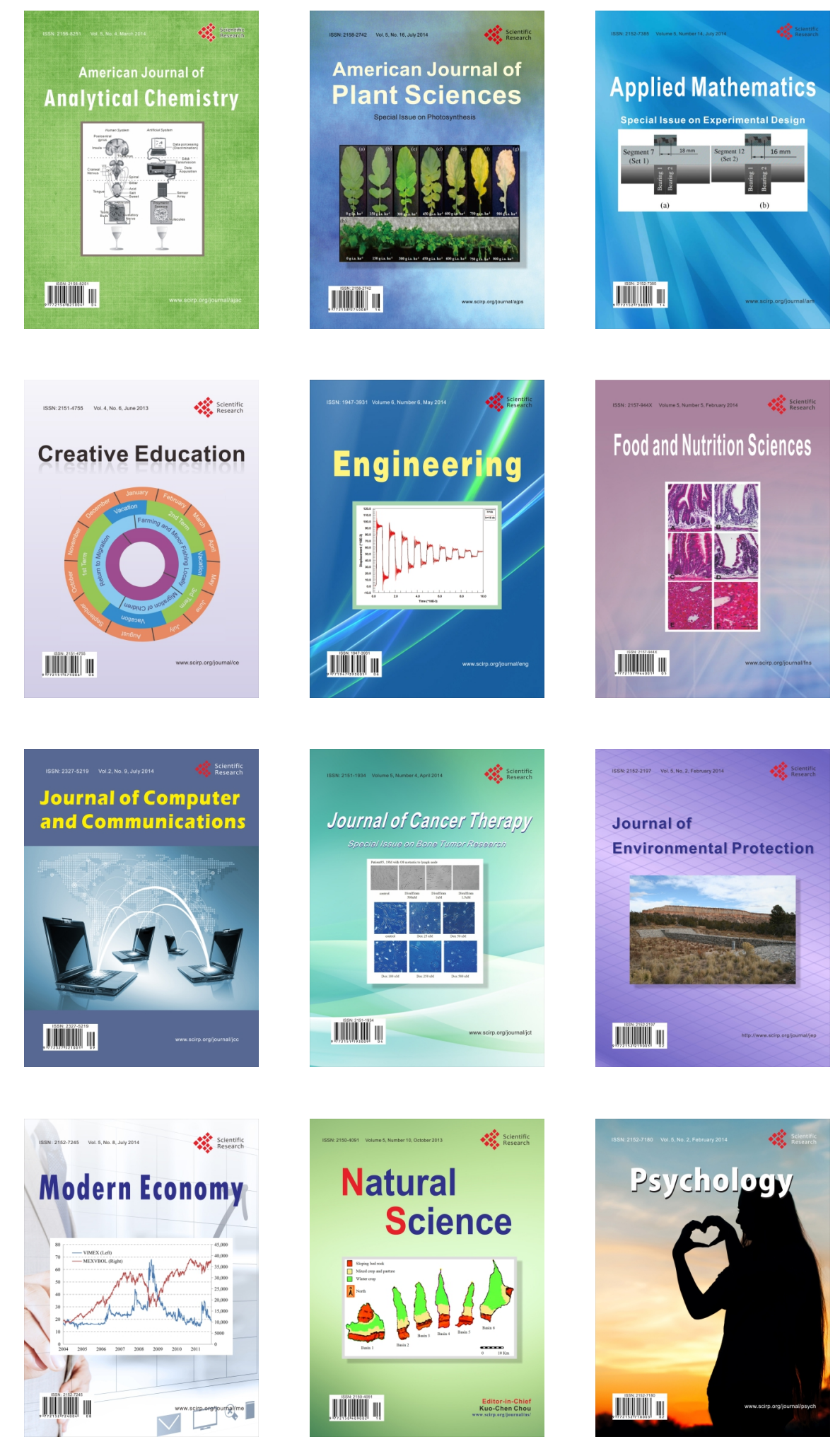